\title{
PENGGUNAAN LEAFLET TERHADAP PENINGKATAN PENGETAHUAN DAN SIKAP KELUARGA BARU
}

\author{
Sri Sumiati AB, Reka Lagora Marsofely \\ Politeknik Kesehatan Kementerian Kesehatan Bengkulu, Jurusan Kebidanan, \\ Jalan Indragiri Nomor 03 Padang Harapan Bengkulu \\ Email :jmkbengkulu@gmail.com
}

\begin{abstract}
A family is a small unite of society that hold an important role as nation asset. The quality family can be reached by doing a set of good planning. A family needs knowledge about a quality family. One of the approaches that can improve the society's willingness to maintan of healthy is that by doing health promotion by using leaflet media. This research aims to know the impact of health promotion toward the knowledge, behaviour, and the action taken by new family to reach a quality family. This research used quasi experimental by planning of non-equivalent control group design. The samples were the men and women that have just married that were 44 persons. The finding of the research showed that there were any impacts of health promotion by using leaflet media toward the knowledge and the action of new family in reaching a quality family. Therefore, there is a need to increase health promotion using leaflet media, so it can improve the knowledge and the behaviour of the society about the quality family so they can make it.
\end{abstract}

Keywords: health promotion, knowledge, behaviour.

\begin{abstract}
Abstrak: Sebuah keluarga merupakan gabungan kecil masyarakat yang memegang peranan penting sebagai aset negara. Kualitas keluarga bisa dicapai dengan melakukan serangkaian perencanaan yang baik. Keluarga membutuhkan pengetahuan tentang keluarga yang berkualitas. Salah satu pendekatan yang dapat meningkatkan kesediaan masyarakat untuk menjaga kesehatan adalah dengan melakukan promosi kesehatan dengan menggunakan media leaflet. Penelitian ini bertujuan untuk mengetahui dampak promosi kesehatan terhadap pengetahuan, perilaku, dan tindakan keluarga baru untuk mencapai kualitas keluarga. Penelitian ini menggunakan kuasi eksperimen dengan perencanaan rancangan kelompok kontrol non-ekuivalen. Sampelnya adalah pria dan wanita yang baru menikah itu 44 orang. Temuan penelitian menunjukkan bahwa ada dampak promosi kesehatan dengan menggunakan media leaflet terhadap pengetahuan dan tindakan keluarga baru dalam mencapai keluarga yang berkualitas. Oleh karena itu, ada kebutuhan untuk meningkatkan promosi kesehatan menggunakan media leaflet, sehingga dapat meningkatkan pengetahuan dan perilaku masyarakat tentang kualitas keluarga sehingga mereka dapat mewujudkannya.
\end{abstract}

Kata Kunci: promosi kesehatan, pengetahuan, perilaku.

Pembangunan berwawasan keluarga merupakan pembangunan yang dilakukan secara seksama mempertimbangkan dimensi keluarga sebagai sasaran dan pelaku. Hal ini sekaligus mengarah pada peranan keluarga sebagai pengembang sumber daya manusia potensial dengan mendayagunakan keluarga untuk mempertajam potensi dasar seseorang, dengan demikian pengembangan sumber daya keluarga adalah rangkaian upaya pembangunan, baik yang dilaksanakan oleh pemerintah swasta dan masyarakat untuk mewujudkan keluarga yang berkualitas. Proses mewujutkan keluarga bahagia lahir dan batin dilakukan secara terpadu oleh pemerintah bersama masyarakat melalui pemantapan sosialisasi dan pelaksanaan delapan fungsi keluarga sesuai dengan kondisi tiap-tiap keluarga, 
melalui siklus perkembangan keluarga guna menjadikan setiap anggotanya sebagai insan pembangunan yang produktif dan kompetitif dalam rangka menuju persaingan pasar bebas.

Bangsa Indonesia masih menghadapi masalah dan tantangan yang sangat kompleks. Hasil Riset Kesehatan Dasar (Riskesdas) Tahun 2010 diketahui bahwa 47\% wanita menikah pada usia di bawah 20 tahun, bahkan angka kelahiran pada kelompok umur 15-19 tahun (Age Spesific Rate/ASFR) di pedesaan menunjukkan proporsi yang lebih besar dibandingkan di perkotaan. Ibu yang berusia di bawah 20 tahun akan menghadapi resiko kehamilan dan melahirkan yang lebih besar dibanding ibu yang berusia lebih tinggi. Kondisi ini menjadi kendala untuk dapat melahirkan generasi yang berkualitas.

Perencanaan keluarga yang berkualitas dimulai dengan keluarga didasari perkawinan yang sah menentukan usia kawin yang ideal, usia melahirkan yang ideal, memenuhi wawasan ke depan bertanggung jawab, komitmen tinggi untuk hidup mandiri, mampu hidup harmonis, memiliki jumlah anak yang ideal, sehat dan sejahtera menjadi prasyarat untuk melahirkan generasi yang berkualitas.

Upaya mewujudkan SDM yang berkualitas saat ini dan dimasa mendatang menjadi sangat penting untuk menjawab tantangan zaman seiring dengan munculnya berbagai dampak dari era global dan modernisasi kehidupan, oleh karena itu, keluarga dituntut untuk mampu memainkan perannya yang strategis untuk memberdayakan seluruh anggota keluarganya dengan memantapkan pelaksanaan fungsi-fungsi keluarga sebagai manifestasi sekaligus aktualisasi dari keluarga yang berkualitas.

Nasution (2010) mengatakan bahwa media promosi kesehatan (leaflet) efektif untuk menaikkan skor pengetahuan dan skor sikap ibu hamil tentang IMD dan ASI Eksklusif di Wilayah Kecamatan Padang Sidempuan Selatan Tahun 2010. Melalui proses promosi kesehatan dengan pendidikan menggunakan media leaflet maka informasi atau pesan mengenai keluarga berkulitas tersebut ditangkap oleh panca indera. Kontak atau pengamatan dilakukan oleh panca indera penglihatan dan pendengaran responden membentuk suatu pengetahuan baru sebagai efek atau respon dari proses penginderaan terhadap stimulus atau pesan mengenai keluarga berkualitas tersebut.

\section{BAHAN DAN CARA KERJA}

Penelitian ini menggunakan quasiexperimental dengan rancangan nonequivalent control group design. Sampel berjumlah 44 pasang keluarga baru, Instrumen pengumpulan data menggunakan Kuesioner. Analisis Data menggunakan uji T test.

\section{HASIL}

\section{Analisa Univariat}

Tabel 1. Karakteristik Responden Berdasarkan Umur dan Pekerjaan

\begin{tabular}{lcccc}
\hline \multirow{2}{*}{ Variabel } & \multicolumn{2}{c}{ Perlakuan } & \multicolumn{2}{c}{ Kontrol } \\
& N & \% & N & \% \\
\hline Umur suami: & & & & \\
$20-30$ & 21 & 95,5 & 21 & 95,5 \\
$>30$ & 1 & 4,5 & 1 & 4,5 \\
& & & & \\
Pekerjaan suami & & & & \\
Swasta & 22 & 100 & 19 & 86,5 \\
PNS & & & 1 & 4,5 \\
Honorer & & & 1 & 4,5 \\
$\quad$ Mahasiswa & & & 1 & 4,5 \\
Jumlah & 22 & $100 \%$ & 22 & $100 \%$ \\
\hline
\end{tabular}

Tabel 1. menunjukkan bahwa hampir seluruh $(95.5 \%)$ responden berusia 20 - 30 tahun, pekerjaan responden yang mendapat perlakuan $(100 \%)$ swasta, dan responden sebagai kontrol hampir seluruh $(86,5 \%)$ swasta. 
Tabel 2. Nilai Rata-rata Tingkat Pengetahuan dan Sikap pada Kelompok Perlakuan dan Kelompok Kontrol

\begin{tabular}{lcccc}
\hline Variabel & \multicolumn{2}{c}{ Perlakuan } & \multicolumn{2}{c}{ Kontrol } \\
& Mean & $\begin{array}{c}\text { Standar } \\
\text { Deviasi }\end{array}$ & Mean & $\begin{array}{c}\text { Standar } \\
\text { Deviasi }\end{array}$ \\
\hline $\begin{array}{l}\text { Pengetahuan: } \\
\text { Pre }\end{array}$ & 11,68 & 0.716 & 10.64 & 1.761 \\
$\quad$ Post & 11,91 & 0.294 & 9.86 & 2.054 \\
Sikap: & & & & \\
$\quad$ Pre & 40.50 & 3.020 & 39.41 & 4.584 \\
Post & 43.18 & 3.541 & 43.45 & 4.847 \\
\hline
\end{tabular}

Berdasarkan tabel 2. terlihat statistik deskriptif rata-rata dan standar deviasi pengetahuan dan sikap responden antara kelompok perlakuan dan kontrol. Rata-rata pengetahuan responden sebelum diberikan perlakuan adalah $(11,68)$ dengan standar deviasi (0.716). Pada pengukuran pengetahuan responden setelah diberikan perlakuan didapat rata-rata (11.91) dengan standar deviasi (0.294). Rata-rata sikap responden sebelum diberikan perlakuan adalah (40.50) dengan standar deviasi (3.020). Pada pengukuran sikap responden setelah diberikan perlakuan didapat ratarata $(43,18)$ dengan standar deviasi (3.541).

Pada Kelompok Kontrol Rata-rata pengetahuan responden pengukuran 1 adalah $(10,64)$ dengan standar deviasi (1,761). Pada pengukuran pengetahuan responden yang kedua didapat rata-rata (9.86) dengan standar deviasi (2.054). Rata-rata sikap responden pengukuran 1 adalah $(39,41)$ dengan standar deviasi (4.584). Pada pengukuran sikap responden yang kedua didapat rata-rata $(43,45)$ dengan standar deviasi $(4,847)$.

\section{Analisis Bivariat}

Analisa bivariat dilakukan untuk melihat perbedaan pengetahuan dan sikap sebelum intervensi dan setelah dilakukan intervensi di analisis dengan $t$-Test Paired. Hasil tersebut dapa di lihat pada tabel 3.

Berdasarkan tabel 3 diketahui bahwa pengetahuan setelah intervensi dengan promosi kesehatan didapat nilai mean 0.227 dengan nilai $\rho=0,135>\alpha 0,05$ yang berarti tidak ada perbedaan pengetahuan responden sebelum dan sesudah diberikan promosi kesehatan. Sikap setelah intervensi dengan promosi kesehatan didapat nilai mean 2.682 dengan nilai $\rho=$ $0,003<\alpha 0,05$ yang berarti ada perbedaan sikap responden sebelum dan sesudah diberikan promosi kesehatan. Pada kelompok kontrol diketahui bahwa pengetahuan pre dan post tanpa diberikan promosi kesehatan didapat nilai mean 0.773 dengan nilai $\rho=0,074>\alpha 0,05$ yang berarti tidak ada perbedaan pengetahuan responden yang tidak diberikan perlakuan. Variabel sikap didapat nilai mean 4.045 dengan nilai $\rho=0,008>\alpha 0,05$ yang berarti tidak ada perbedaan sikap responden yang tidak diberikan perlakuan.

Tabel 3. Analisis Perbedaan Pengetahuan Sikap dan Praktik Kelompok Perlakuan dan Kelompok Kontrol

\begin{tabular}{|c|c|c|c|c|c|c|c|c|c|c|c|c|}
\hline \multirow{3}{*}{ Variabel } & \multicolumn{6}{|c|}{ Perlakuan } & \multicolumn{6}{|c|}{ Kontrol } \\
\hline & \multirow{2}{*}{$\mathbf{N}$} & \multirow{2}{*}{$P$} & \multirow{2}{*}{ Mean } & \multirow{2}{*}{ SD } & \multicolumn{2}{|c|}{$95 \% \mathrm{CI}$} & \multirow{2}{*}{$\mathbf{N}$} & \multirow{2}{*}{$P$} & \multirow{2}{*}{ Mean } & \multirow{2}{*}{ SD } & \multicolumn{2}{|c|}{$95 \% \mathrm{CI}$} \\
\hline & & & & & Lower & Upper & & & & & Lower & Upper \\
\hline Pengetahuan & 22 & 0.135 & 0.227 & 0.685 & 0.531 & 0.077 & 22 & 0.074 & 0.773 & 1.926 & 6.901 & 1.190 \\
\hline Sikap & 22 & 0.003 & 2.682 & 3.747 & 4.343 & 1.021 & 22 & 0.008 & 4.045 & 6.440 & 0.081 & 1.626 \\
\hline
\end{tabular}

\section{PEMBAHASAN}

\section{Pengetahuan}

Berdasarkan hasil penelitian data univariat didapat hasil sebelum dilakukan perlakuan rata-rata pengetahuan responden baik dan setelah dilakukan perlakuan dengan promosi kesehatan didapat hasil rata-rata pengetahuan responden juga baik. Menurut Sarwono, pengetahuan merupakan domain yang penting untuk terbentuknya tindakan seseorang. Penerimaan seseorang terhadap suatu perilaku baru karena suatu rangsangan 
yang melalui proses kesadaran, merasa tertarik, menimbang, mencoba dan akhirnya subyek berperilaku baru sesuai dengan pengetahuan, kesadaran, dan sikapnya terhadap stimulus.

Dari hasil bivariat pengetahuan pada kelompok perlakuan didapat nilai $\rho: 0,135$ yang berarti tidak ada perbedaan pengetahuan responden sebelum dan sesudah diberikan promosi kesehatan. Hasil penelitian ini tidak sejalan dengan penelitian Wibowo (2013) bahwa ada pengaruh promosi kesehatan metode audio visual dan promosi kesehatan metode buku saku terhadap peningkatan pengetahuan penggunaan MSG. Begitu juga dengan penelitian Nasution (2010) bahwa media promosi kesehatan (leaflet) efektif untuk menaikkan skor pengetahuan dan skor sikap ibu hamil tentang IMD dan ASI Eksklusif di Wilayah Kecamatan Padang Sidempuan Selatan Tahun 2010.

Hasil analisis bivariat pada kelompok kontrol (tanpa perlakuan) diperoleh pengetahuan dengan nilai $\rho=0,074>\alpha$ 0,05 yang berarti tidak ada perbedaan pengetahuan responden yang tidak diberikan perlakuan. Pengetahuan atau kognitif merupakan domain yang sangat penting untuk terbentuknya suatu praktik atau tindakan seseorang (overt behavior). Perilaku yang didasari oleh oleh pengetahuan akan lebih langgeng daripada perilaku yang tidak didasari oleh pengetahuan.

Hasil penelitian pada penelitian ini sesuai dengan teori menyatakan bahwa respon merupakan reaksi dari individu ketika menerima stimulus dari suatu proses, stimulus dapat diartikan sebagai hal yang ditangkap oleh panca indera. Stimulus dalam penelitian ini yaitu media leaflet tentang keluarga berkualitas. Melalui proses promosi kesehatan dengan pendidikan menggunakan media leaflet maka informasi atau pesan mengenai keluarga berkualitas tersebut ditangkap oleh panca indera. Kontak atau pengamatan dilakukan oleh panca indera penglihatan dan pendengaran responden membentuk suatu pengetahuan baru sebagai efek atau respon dari proses penginderaan terhadap stimulus atau pesan mengenai keluarga berkualitas tersebut.

\section{Sikap}

Hasil penelitian tentang sikap didapatkan bahwa rata-rata sikap responden sebelum diberikan perlakuan adalah (40.50) dan sikap responden setelah diberikan perlakuan didapat rata-rata $(43,18)$ dengan standar deviasi $(3.541)$. Hal ini berarti terjadi perubahan sikap yang positif setelah responden menerima promosi kesehatan dengan media leaflet.

Menurut Azwar, sikap seseorang terhadap suatu obyek adalah perasaan mendukung atau memihak (favorable) maupun perasaan tidak mendukung atau tidak memihak (unfavorable) pada obyek tertentu, sedangkan Newcomb menyatakan bahwa suatu sikap itu merupakan kesiapan atau ketersediaan untuk bertindak dan bukan merupakan pelaksanaan motif tertentu. Sikap belum merupakan suatu tindakan atau aktivitas, akan tetapi merupakan predisposisi tindakan suatu perilaku.

Hasil analisis bivariat sikap pada kelompok perlakuan diperoleh nilai $\rho=$ $0,003<\alpha 0,05$ yang berarti ada perbedaan sikap responden sebelum dan sesudah diberikan promosi kesehatan. Penelitian ini sejalan dengan penelitian Nasution (2010) bahwa media promosi kesehatan (leaflet) efektif untuk menaikkan skor pengetahuan dan skor sikap ibu hamil tentang IMD dan ASI Eksklusif di Wilayah Kecamatan Padang Sidempuan Selatan. Sama halnya dengan penelitian Gani, dkk (2014) bahwa terdapat perbedaan yang signifikan pada sikap terhadap pencegahan HIV/AIDS sebelum dan sesudah diberikan perlakuan menggunakan media leaflet.

Perubahan sikap terjadi karena adanya intervensi media promosi kesehatan berupa media leaflet yang berisikan informasi 
mengenai keluarga berkualitas. Dalam suatu proses perubahan perilaku, stimulus mampu merubah sikap hanya jika stimulus atau pesan yang menerpa melebihi stimulus semula. Setelah stimulus atau pesan yang disampaikan mendapatkan perhatian dan diterima organisme proses selanjutnya, yaitu kesediaan untuk mengubah sikap. Menurut penelitian Punia (2008), yang membandingkan efektivitas antara media booklet dan leaflet dalam meningkatkan pengetahuan, sikap terhadap pencegahan HIV/AIDS diketahui bahwa leaflet memiliki efektivitas yang sama dengan booklet dalam merubah sikap dimana berdasarkan determinan perilaku adanya perubahan sikap akan mempengaruhi perilaku.

Hasil analisis bivariat sikap pada kelompok tanpa perlakuan diperoleh nilai $\rho=0,008<\alpha 0,05$ yang berarti tidak ada perbedaan sikap responden yang tidak diberikan perlakuan. Promosi kesehatan mempunyai peranan yang sangat penting dalam proses pemberdayaan masyarakat, yaitu memperoleh pembelajaran dari, oleh dan bersama masyarakat sesuai dengan lingkungan sosial budaya setempat, agar masyarakat dapat menolong dirinya sendiri dibidang kesehatan. Media leaflet merupakan bentuk penyampaikan informasi atau pesan pesan kesehatan melalui lembaran yang lipat. Isi informasi dapat dalam bentuk kalimat maupun gambar atau kombinasi.

\section{DAFTAR RUJUKAN}

Bobak, Lodermilk, Jensen. Buku Ajar Keperawatan Maternitas Edisi 4.

Bekti Istiyanto, S., Pentingnya Komunikasi Keluarga, Menelaah Posisi Ibu antara Menjadi Wanita Karir atau Penciptaan Keluarga Berkualitas.

Elwis, L, Simnett, L. 1994. Promosi Kesehatan Petunjuk Praktis. (diterjemahkan oleh Emilia). Yogyakarta: Gadjah Mada University Press.

Gani, A. dkk, 2013. Perbedaan Efektivitas Leaflet dan Poster Produk KPA Kabupaten Jember
Perubahan sikap dipengaruhi oleh tiga faktor, yaitu sumber pesan, pesan (isi pesan), dan penerima pesan. Dua ciri penting dari sumber pesan yaitu kredibilitas dan daya tarik. Aspek penting dalam kredibilitas, yaitu keahlian dan kepercayaan. Sumber pesan menggunakan media leaflet tentang keluarga berkualitas yang dirancang sendiri oleh peneliti, berdasarkan sumber dari BKKBN, oleh karena itu, secara kredibilitas informasi yang tersaji di dalam media merupakan informasi yang akurat dan dapat dipercaya oleh responden. Semakin tinggi tingkat kepercayaan organisme dengan sumber pesan maka akan mudah dipengaruhi dalam perubahan sikapnya.

\section{KESIMPULAN}

Berdasarkan hasil penelitian yang telah diuraikan dapat disimpulkan bahwa ada pengaruh promosi kesehatan dengan metode leaflet terhadap pengetahuan keluarga dalam mencapai keluarga berkualitas, namun hal ini tidak berpengaruh pada sikap keluarga. Peningkatan promosi kesehatan akan lebih efektif dengan peningkatan produksi media leaflet. Leaflet dapat dibagikan kepada pasangan baru menikah, sehingga mampu meningkatkan pengetahuan dan sikap masyarakat untuk mewujudkan keluarga berkualitas. dalam Perilaku Pencegahan HIV/AIDS. Jurnal Ikesma, vol. 10, no. 1.

Irene M. Bobak Margaret D. Jensen, Perawatan Maternitas dan Ginekologi.

Lameshow, S, Hosmer J.r, D.w, Klar, J, Lwanga, S.K, 1997. Besar Sampel Dalam Penelitian Kesehatan, Terj.Pramono, D. I. Yogyakarta: Gadjah Mada University Press.

Panduan-promkes. diakses dariwww.depkes.go.id tanggal 15 Januari 2015. 
Sudiharto, S.Kp, M.Kes. Asuhan Keperawatan Keluarga dengan Pendekatan Keperawatan Transkultural

Sri Sediyaningsih. 2013. Analisis Model Komunikasi Pembentukan Konsep Keluarga Sejahtera di Indonesia. Jurnal Organisasi Manajemen, vol 9, no. 2.

Rismawati, S,. Tantangan Program Keluarga Berencana dalam Menghadapi Ledakan Penduduk Tahun 2030. Fakultas Kedokteran UNPAD Bandung
Remilda, dkk. Pengaruh Pemberian Penyuluhan Kesehatan tentang Kontrasepsi Efektif terhadap Partisipasi Ibu Post Partum dalam Ber-KB. Fakultas Ilmu Kesehatan Universitas Pekalongan.

Wibowo S, Suryani D, 2013. Pengaruh Promosi Kesehatan Metode Audio Visual dan Metode Buku Saku terhadap Peningkatan Pengetahuan Penggunaan MSG pada Ibu Rumah Tangga. Jurnal Kesmas, vol.7, no.2. 